\title{
PROFIL KANDIDIASIS VULVOVAGINALIS DI POLIKLINIK KULIT DAN KELAMIN RSUP PROF. Dr. R. D. KANDOU MANADO PERIODE JANUARI - DESEMBER 2012
}

\author{
${ }^{1}$ Aljufri Syamsudin \\ ${ }^{2}$ Marlyn G. Kapantow \\ ${ }^{2}$ Renate T. Kandou
}

\author{
${ }^{1}$ Kandidat Skripsi Fakultas Kedokteran Universitas Sam Ratulangi Manado \\ ${ }^{2}$ Bagian Ilmu Kesehatan Kulit dan Kelamin Universitas Sam Ratulangi Manado \\ Email: s.aljufrhy_112@yahoo.com
}

\begin{abstract}
Candidiasis vulvovaginalis (candida vulvovaginitis) is an infection of the vagina or vulva by Candida genus, with a variety of clinical manifestations that can occur acutely, chronically, or episodically. This study aimed to determine the profile of candidiasis vuvovaginalis in the Dermatology clinic Prof. Dr. R. D. Kandou Manado during the period of January to December 2012. This was a retrospective study using the medical records of new patients with a diagnosis of candidiasis vulvovaginalis. The results showed that there were 30 patients $(2.73 \%)$ with candidiasis vulvovaginalis among 1096 new patients. It was more commonly found in women with the largest age group 25-44 years, residence in Manado, and as housewives, The most frequent therapy was systemic antifungals and antihistamine. The occurence of this disease was associated with other diseases such as bacterial vaginosis.
\end{abstract}

Keywords: vulvovaginaliscandidosis, candida albicans

\begin{abstract}
Abstrak: Kandidiasis vulvovaginalis (kandidosis vulvovaginalis, kandida vulvovaginitis) adalah infeksi vagina dan atau vulva oleh Genus Candida, dengan berbagai manifestasi klinisnya yang bisa berlangsung akut, kronis atau episodik. Penelitian ini bertujuan untuk mengetahui profil kandidiasis vuvovaginalis di poliklinik Kulit dan Kelamin RSUP Prof. Dr. R. D. Kandou Manado periode Januari - Desember 2012. Penelitian ini dilakukan secara retrospektif dari rekam medik pasien baru dengan diagnosis kandidiasis vulvovaginalis. Hasil penelitian menunjukkan bahwa terdapat 30 pasien (2,73\%) kandidiasis vulvovaginalis dari 1.096 pasien baru, lebih banyak ditemukan pada perempuan dengan kelompok umur 25-44 tahun, didapatkan bahwa wilayah tempat tinggal terbanyak adalah Kota Manado, menurut pekerjaan paling banyak terjadi pada IRT (Ibu rumah tangga), terapi yang banyak digunakan adalah Antijamur sistemik+antihistamin, dan kombinasi kandidiasis vulvovaginalis dengan penyakit lain terbanyak yaitu kandidiasis vulvovaginalis + bakterial vaginosis.
\end{abstract}

Kata kunci: kandidiasis vulvovaginalis, candida albican, penelitian retrospektif

Kandidosis/kandidiasis adalah penyakit jamur yang akut atau subakut disebabkan oleh spesies Candida, biasanya oleh spesies Candida albicans, dan dapat mengenai mulut, vagina, kulit, kuku, bronki, atau paru, kadang-kadang dapat menyebabkan septikemia, endokarditis, atau meningitis. ${ }^{1}$ Kandidiasis vagina adalah jamur pada dinding vagina yang disebabkan oleh genus candida albicans dan ragi (yeast) lain dari genus candida. Penyebab tersering kandidiasis vagina ialah candida albicans yaitu sekitar 85-90\%.

Penyakit kandidiasis vulvovaginalis memengaruhi sebagian besar perempuan selama hidup. Diperkirakan 75\% wanita 
Syamsudin, Kapantow, Kandou: Profil kandidiasis vulvovaginalis...

akan memiliki $>1$ episode per seumur hidup, dan 40-45\% >2. Kebanyakan kasus disebabkan oleh C. albicans (85-90\%), penyebab paling umum dari vaginitis (2025\%) per tahun di AS. ${ }^{2}$

Kandidiasis vulvovaginalis atau kandidosis vulvovaginalis/kandida vulvovaginitis adalah infeksi vagina dan atau vulva oleh Genus Candida, dengan berbagai manifestasi klinisnya yang bisa berlangsung akut, kronis atau episodik. Proses patologik yang timbul bervariasi dari iritasi dan inflamasi sampai supurasi akut, kronis atau reaksi granulomatosis. Oleh karena C. albicans ialah spesies endogen, maka penyakitnya merupakan infeksi oportunistik. Kandidiasis pada wanita biasanya infeksi pertama timbul di vagina yang disebut vaginitis dan dapat meluas sampai vulva (vulvitis); jika mukosa vagina dan vulva keduanya terinfeksi disebut kandidiasis vulvovaginalis. Tanda klinis khas dari kandidiasis mudah dikenal dengan istilah awam sariawan (thrush), dan keputihan (duh vagina) disertai iritasi atau gatal dengan berbagai manifestasi klinisnya yang bisa berlangsung akut, kronik, atau periodik. ${ }^{2-4}$

\section{METODE PENELITIAN}

Penelitian ini bersifat deskriptif retrospektif dengan cara pengambilan data rekam medik pasien Kandidiasis vulvovaginalis di Poliklinik Kulit dan Kelamin RSUP Prof. Dr. R. D. Kandou Manado periode Januari- Desember 2012. Tempat penelitian dilakukan di Rekam Medik dan Poliklinik Kulit dan Kelamin RSUP Prof. Dr. R. D. Kandou Manado. Waktu Penelitian dilakukan pada bulan November-Desember 2013.

Populasi ialah semua pasien yang dirawat di Poliklinik Kulit dan Kelamin RSUP Prof. Dr. R. D. Kandou Manado periode Januari - Desember 2012. Sampel penelitian diambil dari pasien yang didiagnosis kandidiasis vulvovaginalis. Variabel penelitian berdasarkan umur, tempat tinggal, pekerjaan, terapi, kombinasi dengan penyakit lain.

\section{HASIL PENELITIAN}

Tabel 1. Persentase penderita Kandidiasis Vulvovaginalis periode Januari - Desember 2012

\begin{tabular}{ccc}
\hline $\begin{array}{c}\text { Jumlah penderita } \\
\text { rawat jalan }\end{array}$ & $\begin{array}{c}\text { Jumlah } \\
\text { penderita KVV }\end{array}$ & (\%) \\
\hline 1096 & 30 & 2,73 \\
\hline
\end{tabular}

Jumlah kunjungan pasien periode Januari-Desember 2012 di Poliklinik Kulit dan Kelamin RSUP Prof. Dr. R. D. Kandou Manado sebanyak 1.096 orang; 30 (2,73\%) pasien didiagnosis kandidiasis vulvovaginalis.

Distribusi menurut kelompok umur menunjukkan 25-44 tahun merupakan kelompok umur yang paling sering menderita kandidiasis vulvovaginalis dengan jumlah 12 (40\%) penderita, diikuti oleh kelompok umur 45-64 tahun 10 (33,33\%) penderita.

Tabel 2. Distribusi penderita KVV menurut kelompok umur

\begin{tabular}{ccc}
\hline $\begin{array}{c}\text { Umur } \\
\text { (tahun) }\end{array}$ & Jumlah & $\mathbf{( \% )}$ \\
\hline$<1$ & 0 & 0 \\
$1-4$ & 0 & 0 \\
$5-14$ & 0 & 0 \\
$15-24$ & 7 & 23,34 \\
$25-44$ & 12 & 40 \\
$45-64$ & 10 & 33,33 \\
$>65$ & 1 & 3,33 \\
\hline Total & 30 & 100 \\
\hline
\end{tabular}

Tabel 3. Distribusi penderita KVV menurut tempat tinggal

\begin{tabular}{ccc}
\hline Wilayah & $\begin{array}{c}\text { Jumlah } \\
\text { penderita }\end{array}$ & $\mathbf{( \% )}$ \\
\hline Kota Manado & 15 & 50 \\
Kab. Minahasa & 4 & 13,34 \\
Kab. Minahasa utara & 2 & 6,66 \\
Kab. Minahasa selatan & 3 & 10 \\
Kab. Minahasa & 1 & 3,34 \\
tenggara & & \\
Kota Bitung & 1 & 3,34 \\
Kota Kotamubagu & 1 & 3,34 \\
Kab. Sitaro & 3 & 10 \\
\hline Total & 30 & 100 \\
\hline
\end{tabular}


Tabel 4. Distribusi penderita KVV menurut pekerjaan

\begin{tabular}{ccc}
\hline Pekerjaan & Jumlah & $(\%)$ \\
\hline IRT & 15 & 50 \\
PNS & 7 & 23,33 \\
Swasta & 4 & 13,33 \\
Pelajar & 2 & 6,67 \\
Tidak Bkerja & 2 & 6,67 \\
\hline Total & 30 & 100 \\
\hline
\end{tabular}

Berdasarkan tempat tinggal yang dilihat, didapatkan bahwa wilayah tempat tinggal terbanyak adalah Kota Manado sebanyak 15 (50\%) penderita, disusul dengan Kabupaten Minahasa 4 (13,34\%) penderita.

Tabel 5. Distribusi penderita KVV berdasarkan terapi

\begin{tabular}{|c|c|c|}
\hline Terapi & Jumlah & $(\%)$ \\
\hline Antijamur sistemik & 6 & 20 \\
\hline $\begin{array}{c}\text { Antijamur } \\
\text { sistemik+antijamur } \\
\text { topical }\end{array}$ & 4 & 13,33 \\
\hline $\begin{array}{c}\text { Antijamur } \\
\text { sistemik+antihistami } \\
\mathrm{n}\end{array}$ & 8 & 26,60 \\
\hline $\begin{array}{l}\text { Antijamur } \\
\text { topikal+antihistamin }\end{array}$ & 1 & 3,34 \\
\hline $\begin{array}{c}\text { Antijamur } \\
\text { sistemik+antijamur } \\
\text { topical+antihistamin }\end{array}$ & 3 & 10 \\
\hline $\begin{array}{c}\text { Antijamur } \\
\text { sistemik+antijamur } \\
\text { topical+antihistamin+ } \\
\text { PPI }\end{array}$ & 4 & 13,33 \\
\hline $\begin{array}{c}\text { Antijamur sistemik+ } \\
\text { PPI }\end{array}$ & 1 & 3,34 \\
\hline $\begin{array}{c}\text { Antijamur } \\
\text { sistemik+antihistami } \\
n+P P I\end{array}$ & 2 & 6,66 \\
\hline $\begin{array}{c}\text { Antijamur } \\
\text { sistemik+PPI+analget } \\
\text { ik }\end{array}$ & 1 & 3,34 \\
\hline Total & 30 & 100 \\
\hline
\end{tabular}

Sebaran penderita Kandidiasis Vulvovaginalis menurut pekerjaan paling banyak terjadi pada IRT yaitu sebanyak 15 (50\%) penderita, disusul PNS yaitu sebanyak 7 (23,33\%) penderita.

Terapi yang banyak digunakan adalah
Antijamur sistemik $\quad+$ antihistamin (26,66\%) penderita, diikuti Antijamur sistemik 6 (20\%) penderita.

Tabel 6. Distribusi penderita KVV dengan kombinasi penyakit lain

\begin{tabular}{ccc}
\hline $\begin{array}{c}\text { Kombinasi } \\
\text { penyakit KVV }\end{array}$ & $\begin{array}{c}\text { Jumlah } \\
\text { penderita } \\
\text { KVV }\end{array}$ & $\begin{array}{c}\text { Persentase } \\
(\%)\end{array}$ \\
\hline KVV+BV & 11 & 36,66 \\
KVV+KA & 2 & 6,68 \\
KVV+IGNS & 2 & 6,68 \\
KVV+BV+KA & 1 & 3,33 \\
KVV+BV+Ulkus & 1 & 3,33 \\
basialis & & \\
KVV+BV+KK & 2 & 6,68 \\
KVV+KK+KA & 1 & 3,33 \\
KVV+BV+DSC & 1 & 3,33 \\
KVV+Herpes & 1 & 3,33 \\
genital & & \\
KVV+KO & 1 & 3,33 \\
KVV tanpa & 7 & 23,32 \\
kombinasi & & \\
\hline Total & 30 & 100 \\
\hline
\end{tabular}

Ket :

$\mathrm{BV}=$ Bakterial Vaginosis, $\mathrm{KA}=$ Kondiloma Akuminata, IGNS = Infeksi Genital Non Spesifik, $\mathrm{KK}=$ Kandidosis Kutis, $\mathrm{KO}=$ Kandidosis Oral, DSC $=$ Dermatitis Superimposed Candida Kombinasi kandidiasis vulvovaginalis dengan penyakit lain terbanyak yaitu, KVV+BV 11 (36,66\%) penderita, diikuti dengan $\mathrm{KVV}+\mathrm{KA} 2$ orang (6,68\%), KVV+IGNS 2 (6,68\%) penderita, KVV+BV+Kandidosis Kutis 2 orang (6,68\%) penderita.

\section{BAHASAN}

Pada penelitian retrospektif di Poliklinik Kulit dan Kelamin RSUP Prof. Dr.R.D. Kandou Manado periode November - Desember 2013 didapatkan jumlah penderita Kandidiasis Vulvovaginalis sebanyak 30 orang (2,73\%) dari 1096 orang penderita kulit dan kelamin.

Dalam penelitian, distribusi penderita kandidiasis vulvovaginalis menurut kelompok umur, didapatkan bahwa kelompok umur 25-44 tahun merupakan yang paling sering menderita kandidiasis vulvovaginalis dengan jumlah sebanyak 19 orang (40\%), kemudian diikuti oleh kelompok umur 45-64 tahun 10 orang 
(33,33\%), $15-24$ tahun $7 \quad(23,34 \%)$ penderita, >65 tahun 1 (3,33\%) orang, sedangkan pada usia $<1$ tahun, 1-4 tahun dan 5-14 tahun tidak terdapat satupun penderita kandidiasis vulvovaginalis. Hal ini berkaitan dengan hubungan seks yang akan menyebabkan laktobasilus menjadi kurang dominan dan $\mathrm{pH}$ vagina akan meningkat akibat disebabkan oleh semen. Laktobasilus yang menghasilkan $\mathrm{H} 2 \mathrm{O} 2$ merupakan bakteri flora normal yang terpenting karena dianggap dapat memberkan ketahanan dan mencegah invasi atau berkembangnya kandida. Disamping itu peningkatan persentase koitus dapat menimbulkan trauma yang menyebabkan pertumbuhan kandida meningkat. ${ }^{5}$ Kemungkinan juga berhubungan dengan gangguan imunologis, seperti penyakit infeksi dan keganasan yang menekan daya tahan tubuh. ${ }^{6}$

Berdasarkan tempat tinggal yang dilihat per kota/kabupaten, didapatkan bahwa wilayah tempat tinggal terbanyak adalah Kota Manado sebanyak 15 orang ( 50\%). Disusul dengan beberapa Kabupaten, yaitu Kabupaten Minahasa 4 orang (14\%), Minahasa Selatan dan Sitaro 3 orang (10\%), Minahasa Utara 2 orang (7\% ), Minahasa Tenggara dan Bitung serta Kotamubagu 1 orang (3\%). Hal ini disebabkan karena tempat penelitian yaitu RSUP Prof. Dr. R. D. Kandou berada di Kota Manado, sehingga mudah dijangkau oleh penderita yang bertempat tinggal di Kota Manado.

Berdasarkan pekerjaan, didapatkan bahwa yang terbanyak menderita Kandidiasis Vulvovaginalis adalah pada IRT yaitu sebanyak 15 orang (50\%) penderita, disusul PNS yaitu sebanyak 7 orang (23,33\%) penderita, Swasta sebanyak 4 orang (13,33\%) penderita, pelajar 2 orang (6,67\%) penderita, dan tidak bekerja 2 orang (6,67\%) penderita. Hal ini berhubungan dengan kebiasaan dan pekerjaan yang banyak berhubungan dengan air, sehingga mempermudah invasi kandida. ${ }^{7}$

Berdasarkan terapi, didapatkan bahwa terapi yang banyak digunakan adalah
Antijamur sistemik + antihistamin8 orang (26,66\%), diikuti Antijamur sistemik 6 orang (20\%), Antijamur sistemik + antijamur topikal 4 orang (13,33\%), Antijamur sistemik + antijamur topikal + antihistamin + PPI 4 orang (13,33\%), Antijamur sistemik + antijamur topikal + antihistamin 3 orang (10\%), Antijamur sistemik + antihistamin + PPI 2 orang (6,66\%), antijamur topikal + antihistamin 1 orang (3,34\%), antijamur sistemik + PPI 1 orang (3,34\%), antijamur sistemik + PPI + analgetik 1 orang (3,34\%). Hal ini berhubungan dengan pemberian obat anti jamur sistemik untuk pengobatan infeksi jamur superfisial dan sistemik (deep mikosis) dikarenakan Infeksi sistemik lebih sulit diobati, memerlukan terapi jangka panjang dan obat yang tersedia sering menyebabkan efek samping yang berat, sehingga dikombinasikan dengan antihistamin. $^{7}$

Berdasarkan kombinasi dengan penyakit lain, dapat dilihat bahwa kombinasi kandidiasis vulvovaginalis dengan penyakit lain terbanyak yaitu, KVV+BV 11 orang (36,67\%), diikuti dengan $\mathrm{KVV}+\mathrm{KA} 2$ orang $(6,68 \%)$, KVV+IGNS 2 orang (6,68\%), $\mathrm{KVV}+\mathrm{BV}+\mathrm{KI} \quad 1$ orang $(3,33 \%)$, $\mathrm{KVV}+\mathrm{BV}+\mathrm{KA} \quad 1$ orang $(3,33 \%)$, $\mathrm{KVV}+\mathrm{BV}+\mathrm{Ulkus}$ Basial 1 orang (3,33\%), $\mathrm{KVV}+\mathrm{BV}+\mathrm{Kandidosis}$ Kutis 1 orang (3,33\%), KVV+KA+KI 1 orang (3,33\%), $\mathrm{KVV}+\mathrm{BV}+$ Dermatitis Superimposed Candida 1 orang (3,33\%), KVV+Herpes Genital 1 orang (3,33\%), KVV+Kandidosis Oral 1 orang (3,33\%) dan KVV tanpa kombinasi penyakit lain sebanyak 7 orang (23,33\%). Hal ini berkaitan dengan $\mathrm{pH}$ di vagina, pada infeksi KVV $\mathrm{pH}$ vagina normal berkisar antara 4,0-4,5 bila ditemukan $\mathrm{pH}$ vagina lebih tinggi dari 4,5 menunjukkan adanya bakterial vaginosis.

\section{SIMPULAN}

Dari hasil penelitian retrospektif yang dilakukan selama periode NovemberDesember 2013 di Poliklinik Kulit dan Kelamin RSU. Prof. Dr. R. D. Kandou Manado, dapat disimpulkan sebagai 
berikut: Kandidiasis vulvovaginalis ditemukan sebanyak 2,73\%, kelompok umur terbanyak 25-44 tahun, tempat tinggal tebanyak ialah Kota Manado, pekerjaan yang terbanyak Ibu Rumah Tangga, Terapi yang banyak digunakan ialah Antijamur sistemik + antihistamin, dan kombinasi dengan penyakit lain terbanyak ialah bakterial vaginosis.

\section{SARAN}

Perlunya kelengkapan dan kejelasan dalam pengisian status penderita di bagian rekam medik untuk memperlancar penelitian selanjutnya. Juga perlu adanya penelusuran dan pencatatan mengenai faktor predisposisi yang dimiliki tiap pasien, sehingga dapat dilakukan penelitian mengenai faktor predisposisi kandidiasis vulvovaginalis.

\section{DAFTAR PUSTAKA}

1. Kuswadji. Kandidosis. Dalam : Djuanda A, Hamzah M, Aisah S. Penyunting. Ilmu penyakit kulit dan kelamin. Ed 6. Jakarta: FKUI; 2010. p. 106 - 109

2. Steece R. Bacterial Vaginosis, Vulvovaginal Candidiasis, and Trichomoniasis dalam Society of Armed Forces Medical Laboratory
Scientists (SAFMLS) 2011. Available From

http://www.safmls.org/2011/2011\%2 0Presentations/W\%2033/Bacterial\%2 0Vaginosis,\%20Trichomoniasis, $\% 20$ and\%20Vulvovaginal\%20Candidiasis .pdf. Access On: 6 oktober 2013

3. Sobel JD. Vaginitis. N Engl J Med 1997;337:1896-1903.

4. Suyoso S. Kandidiasis Mukosa. 2011. Available from http://rsudrsoetomo.jatimprov.go.id/id /index.php?option=com_docman\&tas $\mathrm{k}=$ doc_download\&gid=83\&Itemid $=1$ 18. Access on : 6 October 2013

5. Krisnarto E. Hubungan Antara Kadida Dalam Air Bak Kamar Mandi Penderita Vaginitis Dengan Kejadian Kandidiasis Vulvovaginitis. Program Pasca Sarjana Ilmu Kesehatan Kulit dan Kelamin Universitas Diponogoro 2004. Available From: http://eprints.undip.ac.id/12378/ Access On: 5 Oktober 2013

6. Pudjiati SR, Soedarmadi. Kandidosis Vulvovaginal. Dalam : Dailil S.F, Makes W.I.B, Zubier F. Penyunting. Infeksi Menular Seksual edisi keempat. Jakarta. Badan pnerbit FKUI 2011. p. 171-177

7. Siregar RS. Penyakit Jamur Kulit. Ed 2. Jakarta: EGC, 2013. p. 45-46. 